\title{
Albite-chlorite and talc-chlorite deposits in metasedimantary and granitoid rocks of central Sardinia (Italy)
}

\author{
MADDALENA FIORI ${ }^{1}$; SILVANA MARIA GRILLO ${ }^{2}$ \\ ${ }^{1}$ Istituto di Geologia Ambientale e Geoingegneria, C.N.R. Cagliari, Italy, fiori@unica.it \\ 2Dipartimento di Geoingegneria e Tecnologie Ambientali, Cagliari University, Italy, grillo@unica.it
}

(Received October 2002 Accepted December 2002)

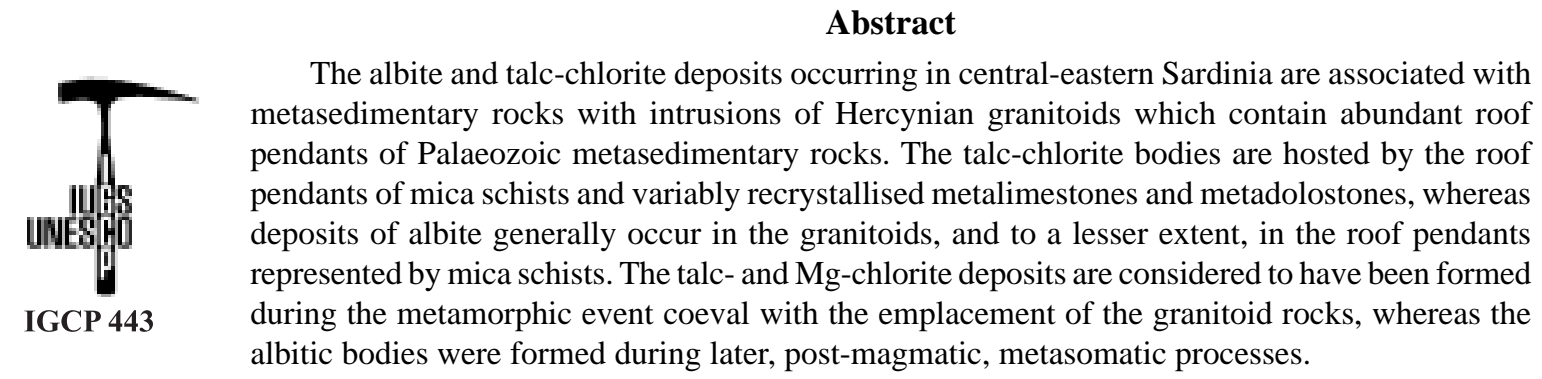

Key words: Talc; Chlorite; Petrology; Central Sardinia.

\section{Introduction}

Sardinia is a major producer of albite, talc and $\mathrm{Mg}$ chlorite for domestic and export markets. The Ottana and Orani mining district in central Sardinia produces highquality albite and talc accompanied by varying proportions of $\mathrm{Mg}$-chlorite. The extraction of albite (An $<5 \%$, Or $<1 \%$ ) started in the 1980s with an annual production of 500,000 $-600,000$ tonnes grading 7-8\% $\mathrm{Na}_{2} \mathrm{O}$.

The talc-Mg-chlorite minerals were already being mined in Sardinia in the 1930's and they still play a very important role in the social life and regional economics. Though a large number of mineralised bodies occur in this area, Sa Matta is the only deposit currently being mined. The economic importance of both the mining and the exploration activities calls for further investigation of these raw materials to gain a deeper insight into the genetic environment viewing to facilitate the search for new deposits.

\section{Geological background}

The Hercynian granitoid rocks crop out in central Sardinia with roof pendants of Palaeozoic metasedimentary rocks. Elsewhere, these rocks are partially overlain by Tertiary volcanic rocks, both trending NE-SW (Fig. 1.).
In Sardinia, granitoid rocks show variable compositions and were emplaced at different crustal depths. The entire suite of rocks includes syntectonic tonalites, granodiorites, quartz diorites and peraluminous leucogranites; late-tectonic granodiorites and monzogranites composing the bulk of the complex; and post-tectonic leucogranites (Cherchi \& Musumeci, 1992).

The leucogranites are composed of quartz, Kfeldspar (orthoclase and minor microcline), less abundant plagioclase (albite-oligoclase) and rare $\mathrm{Fe}$ bearing biotite, which is commonly chloritised. Accessory minerals include apatite, zircon and allanite (Fiori \& Grillo, 1991).

Monzogranites and granodiorites are medium grained and equigranular. Oligoclase-andesine plagioclase $(30-40 \% \mathrm{Ab})$ is the most abundant mineral. Other rock-forming minerals are K-feldspar, quartz, biotite and hornblende. Common accessory minerals are apatite, epidote, zircon, titanite and magnetite.

Locally, the granitoids have undergone various degrees of albitisation, ranging from weakly albitised varieties to true albitites.

The partially albitised granites are less abundant than the albitite s.s. and crop out discontinuously. They 


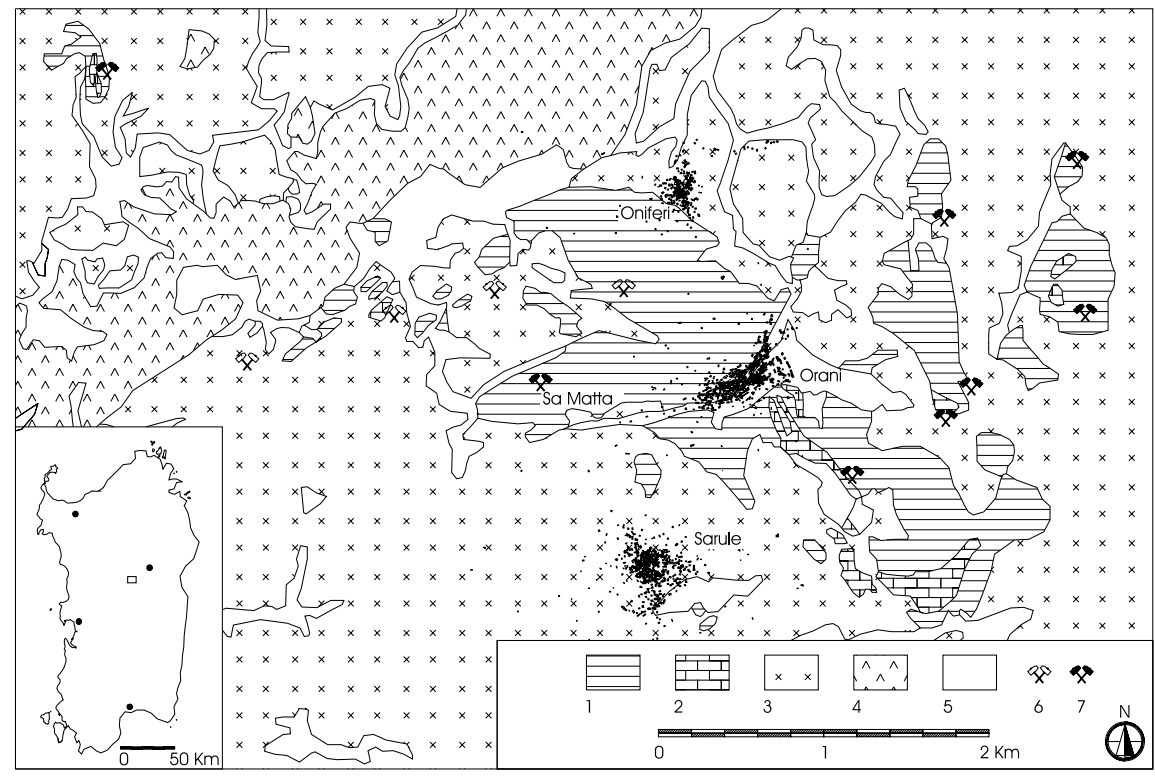

Fig. 1. A simplified geological map showing the major geological units of central Sardinia and the location of albite-Mg chlorite and talc-Mg chlorite occurrences. Palaeozoic: 1 metasedimentary rocks, 2 - carbonate rocks, 3 - granitoid rocks; Tertiary: 4 - volcanic rocks; Quaternary: 5 - superficial deposits; Industrial mineral occurrences: 6-albite-Mg-chlorite; 7 - talc and Mg-chlorite.

maintain most of the textural characteristics of the protolith. Macroscopically, the albitised granites are distinguished from the unaltered varieties by their lighter colour and more intense fracturing.

The metasedimentary rocks of the study area are represented by mica schists, metalimestones and subordinate garnet-rich marbles.

\section{Albite and albite-chlorite bodies}

The major albite-chlorite occurrences are hosted by the granitoid rocks. However, locally, the roof pendants of the mica schists were also affected by albitisation. The albitites do not retain original magmatic textures. The typical mineral assemblage of the albitites s.s. includes albite (Fig. 2) and quartz, with a lesser amount of clinochlore (Fig. 3); accessory minerals are epidote, titanite, rutile and apatite. The K-feldspar has been completely replaced by albite that shows typical chessboard twinning (Fig. 4).

The albite ore bodies occur along structures belonging to a regional ENE-WSW system, which formed during the late stages of the Hercynian orogeny, and was reactivated during the Alpine orogenic event (Atrhaud \& Matte, 1975; Atzori et al., 1986).
The mineralised bodies are generally of lenticular shape, which is controlled by fracture systems that developed parallel and orthogonal to the Hercynian fault complex. The albite deposits are most voluminous and represent a major mineralising event. The deposits are composed of metasomatic and minor magmatic albite (Bornioli et al., 1996).

\section{Talc and Mg-chlorite bodies}

Major talc-chlorite mineral occurrences in the central-eastern part of Sardinia are still being exploited. Their origin is related to the Hercynian metamorphic event and emplacement of the granitoid rocks. Thus, they differ from the metasomatic albitites.

The talc-Mg-chlorite bodies formed where the roof pendants of metasedimentary rocks are larger and more volumous (Fig. 1). The roof pendants are composed of mica schists consisting of quartz, biotite, muscovite, subordinate garnet (grossular and almandine), sillimanite and andalusite. The mica schists are commonly intercalated with variably recrystallised metalimestone, dolomitic metalimestone and metadolostone. In places, this rock assemblage is accompanied by talc $-\mathrm{Mg}$-chlorite rocks. A garnet-bearing skarnoid facies has also been 


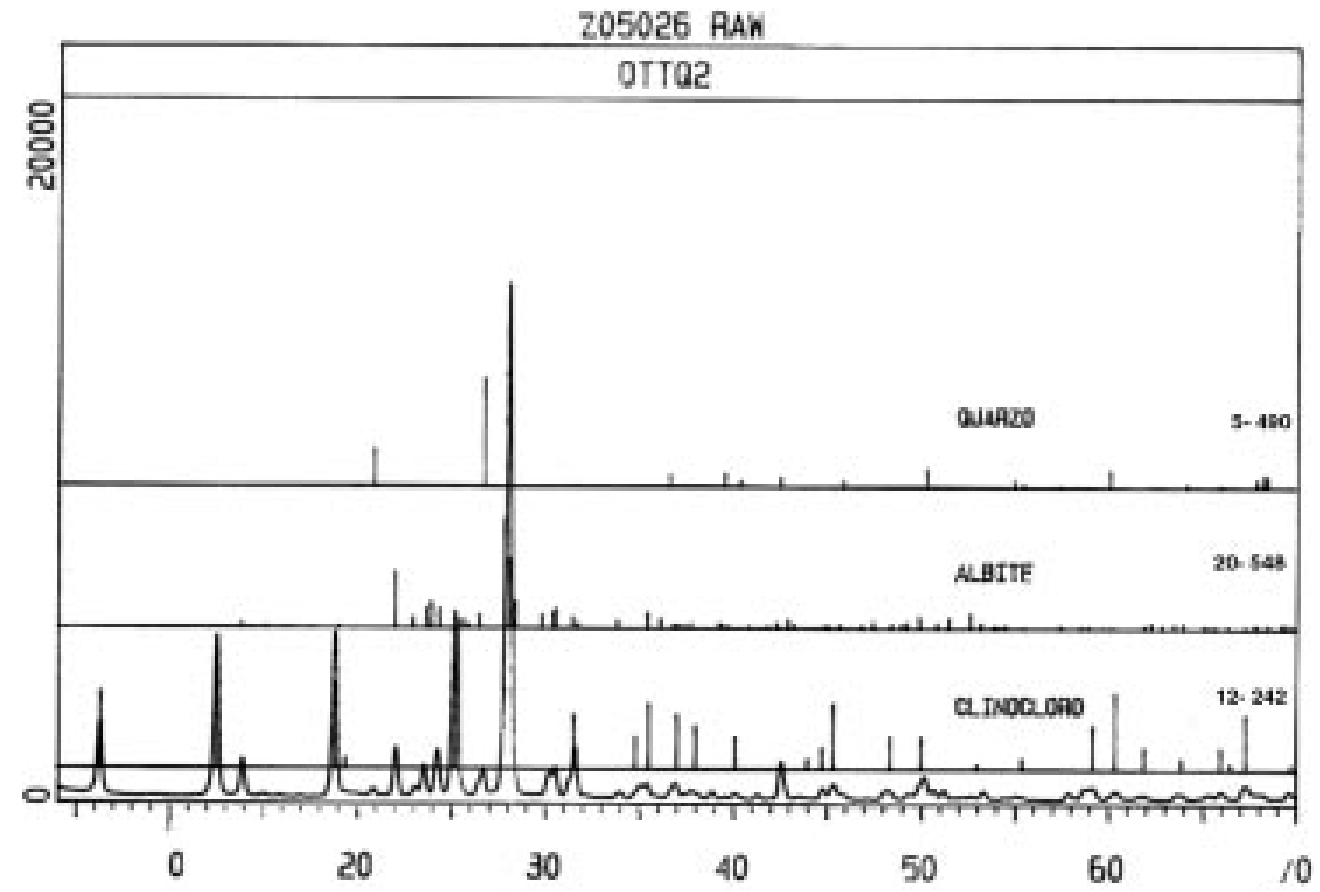

Fig. 2. X-ray diffraction pattern of the albitite $(\mathrm{CuKa})$.

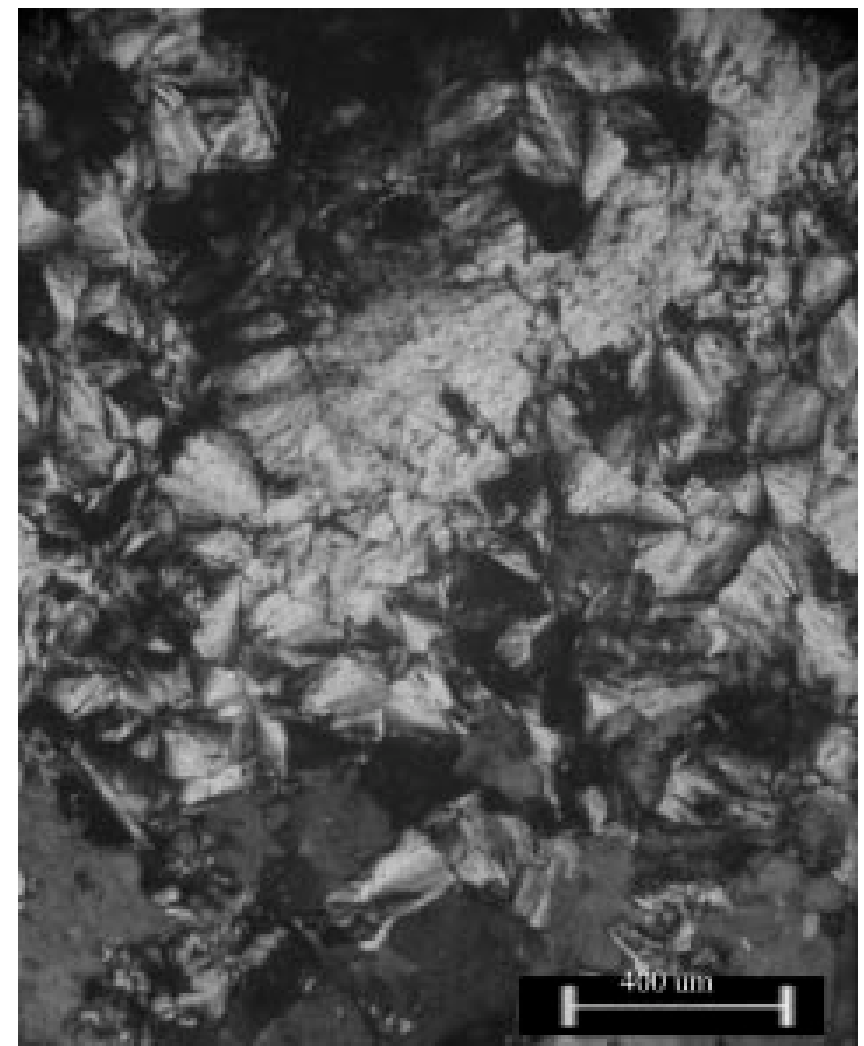

Fig. 3 (foto2). Photomicrographs of radial-fibrous structure of the clinochlore enclosed in albite. Cross-polarised light.

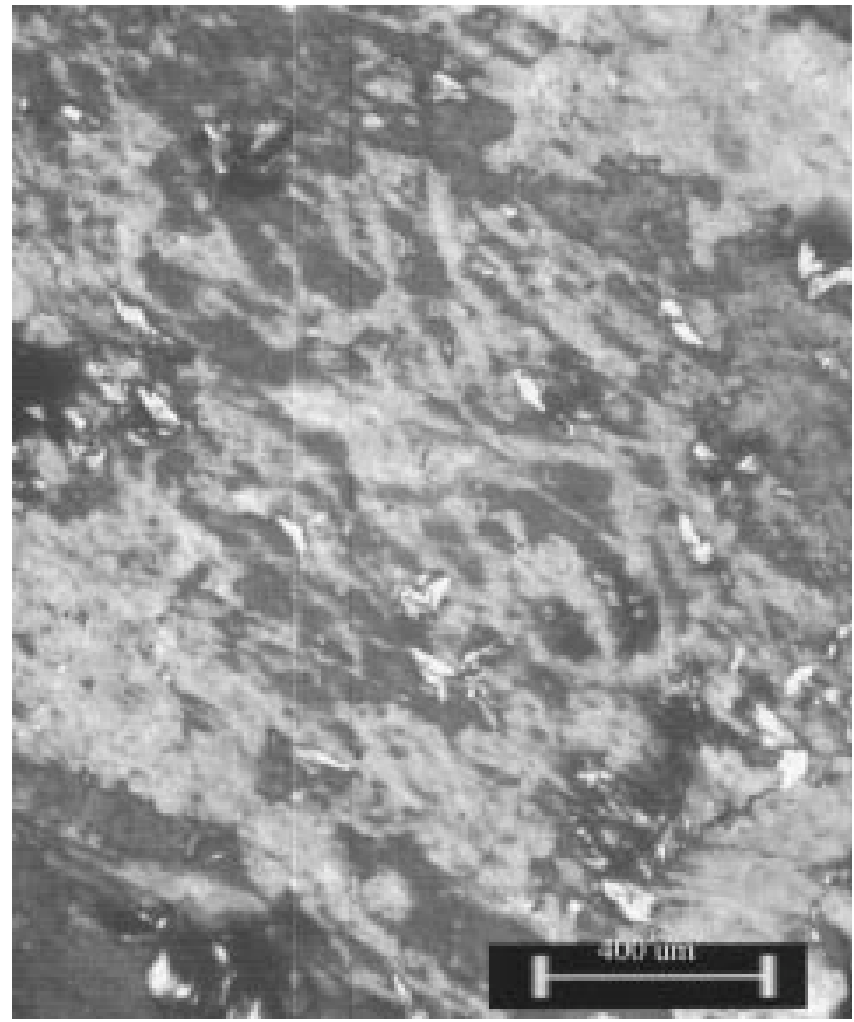

Fig. 4 (foto1). Photomicrographs showing characteristic chessboard texture of the albite with dissemination of the clinochlore (white). Cross-polarised light. 
reported in the area. This is composed of recrystallised, milky quartz, garnet and tremolite. High concentrations of epidote have been observed in proximity to the talcmineralised zones.

A large number of mineralised occurrences have been recognized in the area, but only a few of them can be considered to be of economic importance. The largest of these is the Sa Matta deposit.

\section{The Sa Matta talc-chlorite deposit}

The first mining operations date back to the 1920s. Initially, Sa Matta was developed as an open pit mine which was subsequently converted into a underground mine operating until the mid-1970s, when peak production was attained. However, underground workings ceased in the late 1970s and since then mining has continued as an open pit operation.

In paragenetic terms, three distinct zones are visible (Fig. 5).

In the western portion of the mine, where the rocks are mainly represented by granitoids, $\mathrm{Mg}$-chlorite is the dominant mineral. It is accompanied by quartz and talc, which are generally associated with calcite. In the central part, where major occurrences of carbonate rocks developed, talc is more common and generally microcrystalline. Finally, in the northernmost and economically most important part of the deposit, where the host rocks are largely represented by mica schists and granitoids, the mineralised zones are composed mainly of talc with subordinate $\mathrm{Mg}$-chlorite.

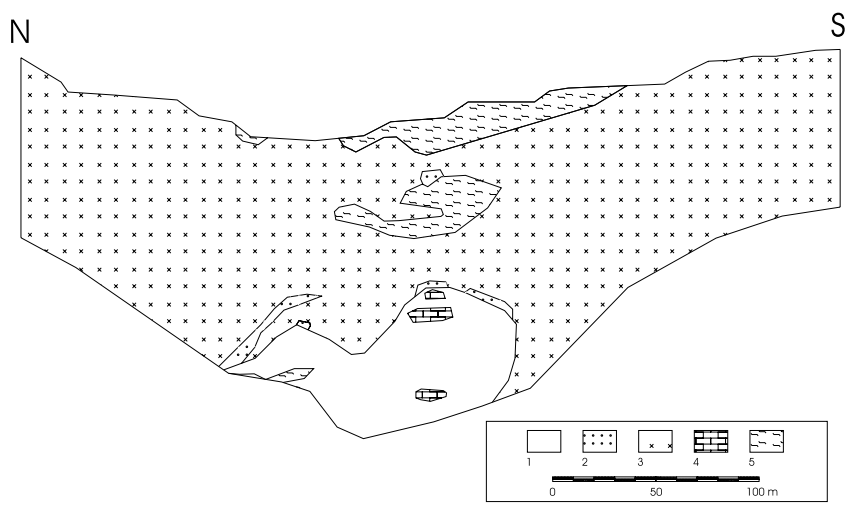

Fig. 5. Schematic geological cross-section of Sa Matta mine. 1 talc-mineralised zones, 2 - Mg-chlorite rocks; 3 - granitoid rocks; 4 - recrystallised metalimestone; 5 - mica schists.
In addition, chloritised and partially albitised granitoid rocks can also be found at Sa Matta.

\section{Results and discussion}

In a geological context where felsic magmatism prevails and carbonate rocks are subordinate, the genesis of the talc and $\mathrm{Mg}$-chlorite bodies has always been a subject of controversy and various hypotheses have been advanced to explain the origin of the magnesium (Righi, 1918; Pavan, 1933; Charrier, 1957; Cavinato, 1964; Massoli Novelli, 1971; Gavoille, 1973; Uras, 1973).

Recent studies suggest that the formation of the talc and Mg-chlorite bodies might have been a 'by-product' of metasomatic albitisation that produced large albite deposits (Garbarino et al., 1993; Fiori et al., 1994).

The above hypothesis was proposed because, until recently, no carbonate rocks had been discovered in the area adjacent to the talc-chlorite deposit. A recently developed open pit mine has, however, exposed both metalimestones and metadolostones (Mannini, 1999) in direct contact with the chlorite-talc mineralised zones. A mineralogical study of the newly exposed rocks has shown the presence of a complex mineral paragenesis consisting of talc, Mg-chlorite (Fig. 6), magnesite (Fig. 7), garnet, tremolite and sillimanite.

It has been observed that the chlorite associated with the albitite bodies has a much lower iron and a much higher $\mathrm{Mg}$ content when compared to those of the chlorite associated with the talc (Fig. 8). The same

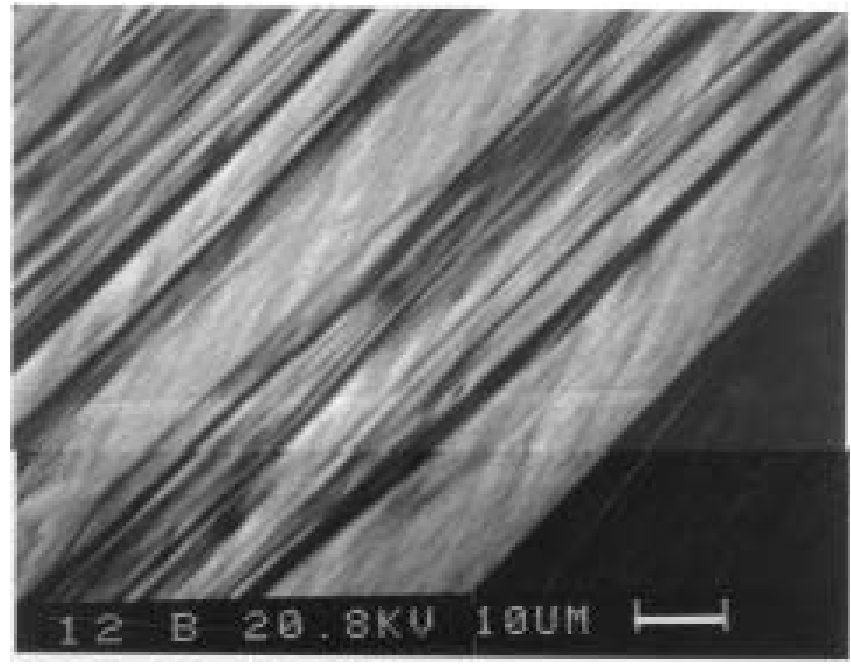

Fig. 6. BSE images of a talc-chlorite sample where the talc is black and the chlorite is white. 


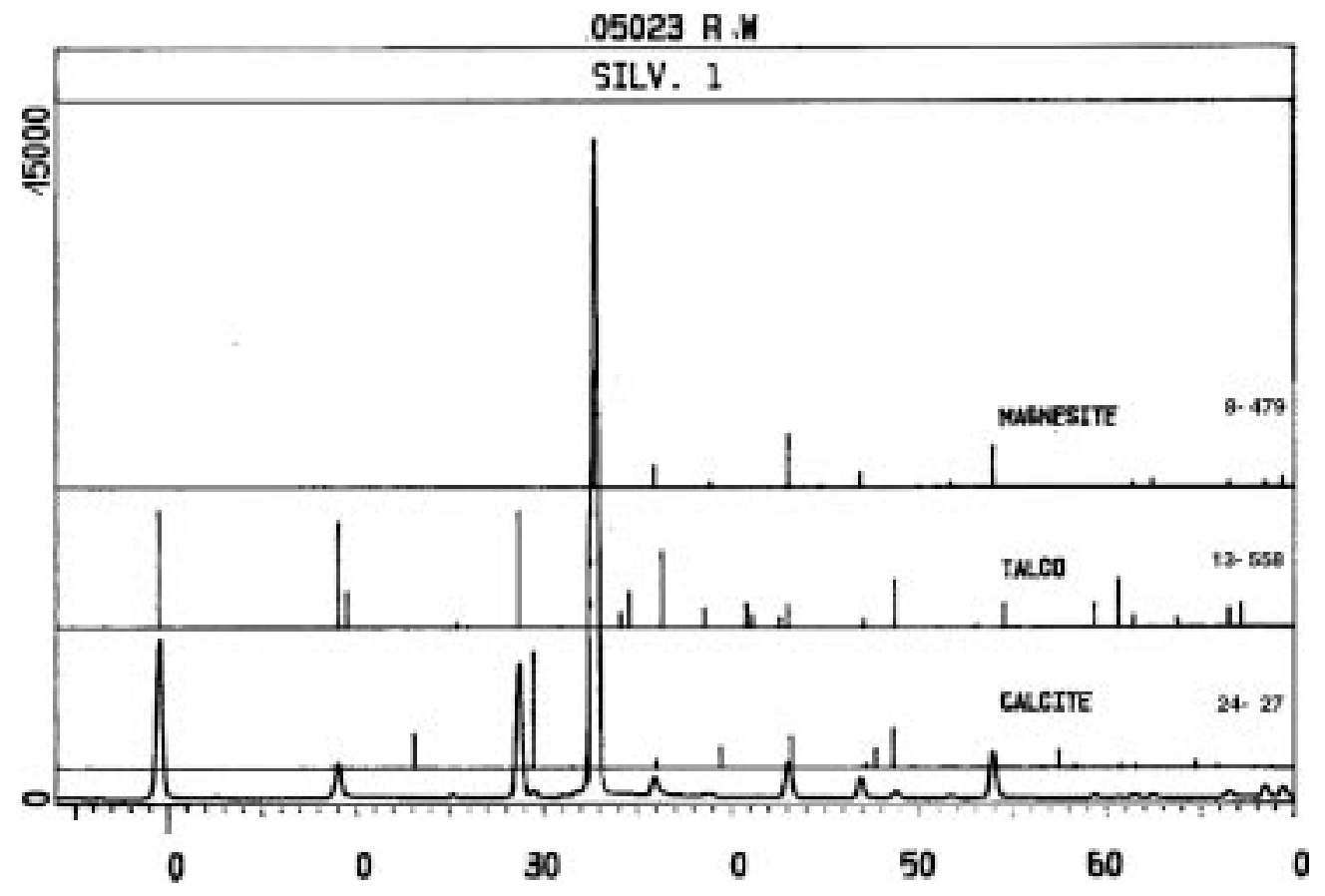

Fig. 7. X-ray diffraction pattern of the talc $(\mathrm{CuKa})$.

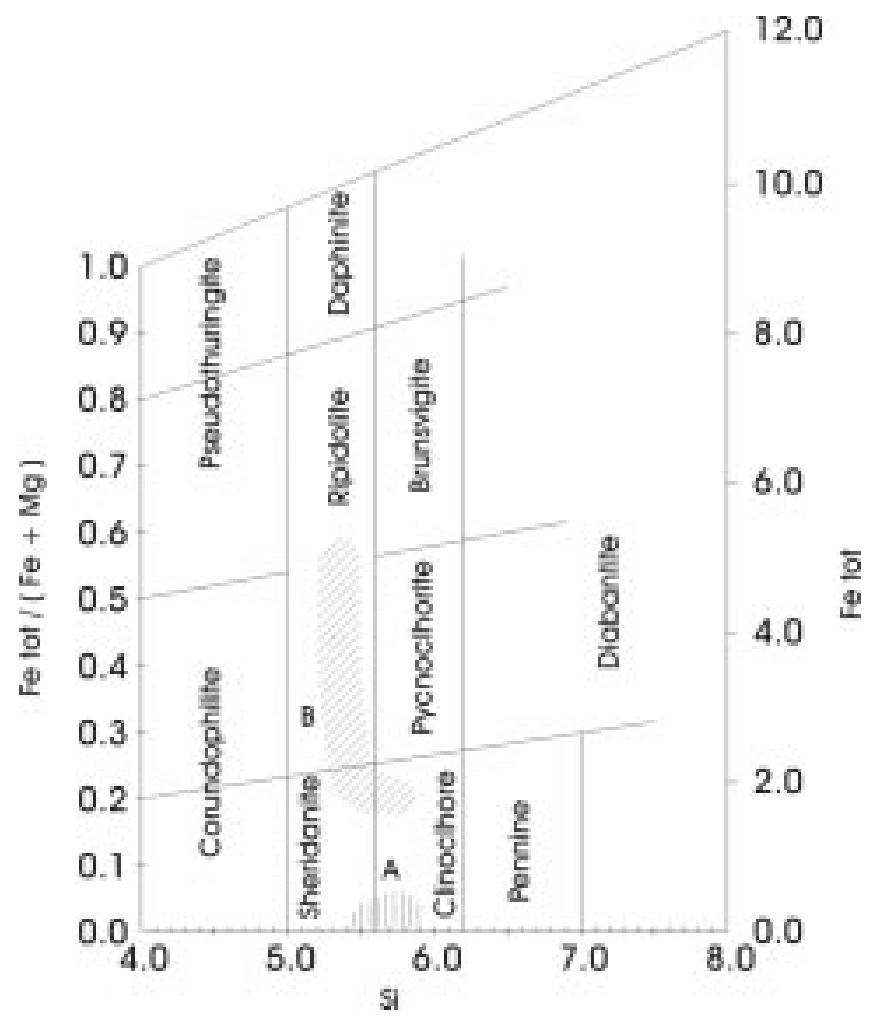

Fig. 8. Chemical classification of chlorites associated with the albitite (A, 59 samples) and talc (B, 40 samples) bodies. 


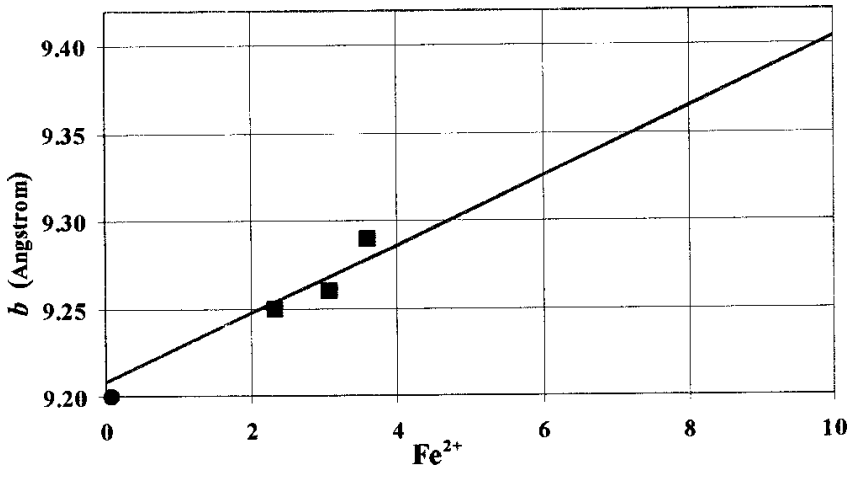

Fig. 9. Cell parameters $b$ versus $\mathrm{Fe}^{2+}$ content in the selected samples of albitites (filled circle) and talc-chloritic bodies (filled squares).

diagram shows that the chlorite associated with the talc tends to contain higher concentrations of $\mathrm{Al}^{\mathrm{IV}}$ in relation to the more extensive replacement of Si (Rice, 1977a and b; Zane et al., 1998).

The compositional differences in these two chlorite phases are also confirmed by the different values of the parameter in cell $b$, which corresponds to the $\mathrm{Fe}^{2+}$ content (Fig. 9).

The new data, together with the discovery of the rocks containing garnet, andalusite and sillimanite, as well as the calcite-chlorite-talc paragenesis and the talc in metacarbonate rocks, led to a rethinking of the previously suggested genetic models.

Firstly, the presence of metadolostones and the talccalcite paragenesis is consistent with the metamorphic origin of the talc, which might have formed in accordance to the theoretically defined reaction: 3 dolomite +4 quartz $+1 \mathrm{H}_{2} \mathrm{O} \rightarrow 1$ talc +3 calcite +3 $\mathrm{CO}_{2}$.

Secondly, this reaction is usually accomplished in the transition from low- to high-grade, greenschist-facies conditions, which is in conflict with the garnetandalusite-sillimanite paragenesis observed in the metasedimentary rocks.

Thirdly, if the garnet-andalusite-sillimanite paragenesis defines the peak-metamorphic conditions, then the talc should have formed either during the retrograde phase of regional metamorphism or during contact-metamorphic event caused by the emplacement of the granitoid intrusions.
At the moment we are not in a position to choose between these two scenarios because of the limitations of the data which do not allow us to discriminate between the regional and contact metamorphic processes. Nevertheless, the differences in the chlorite crystallochemistry suggest that the granitoid-hosted albite-chlorite bodies and the sedimentary rock-hosted talc-chlorite bodies have very likely been formed by two different fluids. If this assumption is correct, then the formation of the talc-chlorite occurrences should be linked to the retrograde phase of the regional metamorphism.

The presence of the magnesite represents a challenge. There is no data suggesting that the magnesite is a metasedimentary phase. Magnesite + calcite is not a stable metamorphic paragenesis although it has been described in metamorphic rocks (e.g. Watts, 1973). However, there are at least two theoretically predicted, metamorphic reactions when the magnesite can form: $(i)$ dolomite $\rightarrow$ magnesite + calcite, $($ ii) plagioclase + chlorite + dolomite $\rightarrow$ quartz + epidote + magnesite. Both these are so-called 'fluid-absent reactions', though the first one requires a higher temperature (for details, see Watts, 1973).

\section{Conclusions}

The currently available data are most consistent with the following model:

(i) The granitoid-hosted albite-chlorite deposits are considered to be the result of post-magmatic, metasomatic processes, as has been suggested previously.

(ii) The talc-chlorite deposits formed either during the retrograde metamorphic event or during contactmetamorphic event caused by the emplacement of the granitoid intrusions. Although the P-T conditions of this retrograde or contactmetamorphic event remain unknown, they must be comparable to those of biotite-actinolite - facies conditions, as required by the theoretically predicted metamorphic reaction.

(iii)It cannot be ruled out that the metasomatic processes responsible for the formation of the albitites may have partially or locally overprinted the talc-chlorite paragenesis. 


\section{References}

Arthaud, F. and Matte, Ph., 1975. Les decrochements tardihercyniens du sud-ouest de l'Europe: Geometrie et essai de reconstitution des conditions de la deformation. Tectonophysics, 25, p. 139-171.

Atzori, P. and Traversa, G., 1986. Post-granitic Permo-Triassic dyke magmatism in eastern Sardinia (Sarrabus p.p., Barbagia, Mandrolisai, Goceano, Baronie and Gallura). Periodico di Mineralogia, 55, p. 203-231.

M. Fiori, S.M.Grillo, R. Bornioli, S. Fadda, C. Marini (1996). Genetic Aspects of albite deposits from Central Sardinia: Mineralogical and Geochemical Evidence. Explor. Mining Geol., Vol.5, pp. 61-72.

Charrier G., 1957. Gli scisti cristallini della Sardegna settrentionale. Boll. S erv. Italia, 79, p 101-205.

Cherchi, G.P., Musumeci, G., 1992. Il complesso granitoide della Sardegna settentrionale. In L. Carmignani, C. Pertusati, S. Barca, Schema dell'evoluzione del basamento sardo, p.157-163.

De Vincenzi Garbarino C., Fiori M., Grillo S.M., Marcello A., Marini C., Pretti S. 1991. Genetic links between albite and chlorite talc minealizations in central Sardinia. Prooceding of second SGA meeting Granada, pp 679-682.

Fiori, M., Grillo, S.M., 1991. Allanite from hercynian granitoids of central Sardinia and its relations with talc-chlorite bodies. Periodico di Mineralogia, 60, p. 55-63.
Gavoille B., 1973. Etude geologique et petrographic du socle et des gites de talc et chlorite de la region d'Orani. Tesi di dottorato.

Mannini, E., 1999. Il giacimento di talco e clorite di Sa Matta. Tesi di laurea, p. 120.

Massoli Novelli R., 1971. Contributo allo studio genetico del talco di Orani. Rend. Ass. Min. Sarda, 76, pp 31.

Pavan G., 1933. Miniere di talco in Sardegna. A.M.S.

Rice J.M., 1977 a. Contact metamorphism of impure dolomitic limestone in the Boulder aureole, Montana. Contr. Mineral. Petrol. 59, 237-259.

Rice J.M., 1977 b. Progressive metamorphism of impure dolomitic limestone in the Marysiville aureole, Montana. Am. J. Sc., 277, pp 1-24.

Uras I., 1973. Guida per l'escursione dei giacimenti di talco di Orani. Itinerari geologici, mineralogici e giacimentologici della Sardegna. E.M.S.A.

Watts, B.J., 1973. Relationship between fluid-bearing and fluid-absent invariant points and the a petrogenetic grid for a greenschist facies assemblage in the system $\mathrm{CaO}-\mathrm{MgO}-\mathrm{Al}_{2} \mathrm{O}_{3}-\mathrm{SiO}_{2}-\mathrm{CO}_{2}-\mathrm{H}_{2} \mathrm{O}$. Contributions to Mineralogy and Petrology, 40, 225-238.

Zane A., Sassi R., Guidotti C.V., 1998. New data on metamorphic chlorite as a petrogenetic indicator mineral, with special regard to greenscschist-facies rocks. Vol. 36, pp 713-726. 